\title{
Микро- и наноразмерные источники излучения ближнего ИК диапазона на кремнии
}

Красильник 3.Ф., Новиков А.В.

ИФМ РАН, 603950, Нижний Новгород, ГСП-105

DOI 10.34077/Semicond2019-34

B последние годы очевиден существенный рост активности в области кремниевой нанофотоники в мире и, в меньшей степени, в России. Если раньше дискутировался вопрос, способны ли, в принципе, гетероструктуры на основе кремния эффективно люминесцировать в ближнем ИК диапазоне на основных телекоммуникационных длинах волн 1,3 и 1,55 мкм, то сегодня уже актуальны вопросы миниатюризации источников излучения для межсоединений на кремнии, интегральной оптики, радиофотоники и др. Говоря о мотивации, прежде всего имеются ввиду задачи преодоления дифракционного предела, манипулирования светом на глубоком субволновом масштабе. За этим видится развитие новых фундаментальных направлений нанофотоники и важные технологические решения, среди которых объединение электроники и оптики в одной интегральной схеме, непреложная задача для создателей интегральных схем следующего поколения. При этом необходимо решить сложные проблемы, связанные с быстрой пересылкой гигантских объемов информации со снижением энергопотребления.

Шаги, направленные на миниатюризацию уже известных полупроводниковых источников до микронного и субмикронных размеров, по большому счету не породили новых труднопреодолимых задач, а напротив, облегчили решение ряда проблем, хорошо известных для источников на основе кремниевых гетероструктур макроразмера. С уменьшением размеров улучшаются такие важные характеристики источников излучения, как пороговый ток, квантовая эффективность, спектральная ширина.

Эффективность излучения связана с эффективностями пространственного ограничения электромагнитного поля и радиационных процессов передачи энергии от усиливающей среды к полю. Вероятность передачи энергии определяется плотностями фотонных и электронных состояний одновременно. Уменьшение размерности усиливающей среды, вплоть до квантовых точек, позволяет более эффективно заселять электроны и дырки в энергетическом пространстве, совмещать спектр эмиссии со спектральной полосой резонатора. Прямым следствием уменьшения размера источника является ускорение радиационного процесса благодаря эффекту Парселла.

Из практически интересных подходов технология гибридных устройств на кремнии сегодня выглядит наиболее продвинутой для создания интегрированных фотонных компонентов на кристалле. Такой подход позволяет использовать преимущества как прямозонности гетероструктур на основе элементов III-V групп, так и пассивных оптических элементов на кремнии.

В докладе обсуждаются результаты исследований в таких актуальных направлениях, как гибридные $\mathrm{A}_{3} \mathrm{~B}_{5} / \mathrm{SiGe} / \mathrm{Si}$ и $\mathrm{A}_{3} \mathrm{~B}_{5} / \mathrm{Si}$ микролазеры на модах шепчущей галереи, фотонные кристаллы на $\mathrm{SiGe} / \mathrm{Si}$ гетероструктурах, диэлектрические нанорезонаторы с $\mathrm{SiGe} / \mathrm{Si}$ наноостровками по материалам работ, выполненных в ИФМ РАН (Алешкин В.Я., Дубинов А.А., Кудрявцев К.Е., Сергеев С.М., Скороходов Е.В., Степихова М.В., Шалеев М.В., Юрасов Д.В., Яблонский А.Н.) совместно с Университетом Лобачевского (Байдусь Н.В.), Санкт-Петербургским академическим университетом (Жуков А.Е., Крыжановская Н.В.), ИТМО (Петров М.И., Богданов А.А., Ермаков О.Е.), Институтом науки и технологий Сколково (Дьяков С.А.), Университетом Мартена Лютера в Халле, Германия (Rutckaia V., Schilling J.). 